\title{
Intraspecific chemical variation within the crustose lichen genus Haematomma: anthraquinone production in selected cultured mycobionts as a response to stress and nutrient supply
}

\author{
Elfie Stocker-Wörgötter · Armin Hager • \\ John A. Elix
}

Received: 16 December 2008/ Accepted: 14 September 2009/Published online: 2 October 2009

(C) Springer Science+Business Media B.V. 2009

\begin{abstract}
The mycobionts isolated from selected species of Haematomma (Haematomma africanum, Haematomma fenzlianum, Haematomma flourescens, Haematomma persoonii, Haematomma stevensiae) have been successfully cultured. The chemical profile of the mycobionts could be effectively influenced and modulated by varying the composition of the nutrient medium using alternative carbohydrates (glucose, sucrose, and polyols). Under artifical laboratory conditions and simulated environmental stress (exposure to UV light, desiccation, and lower temperatures) the mycobionts began producing typical secondary lichen metabolites after an incubation time of 5-6 months. Modified Lilly and Barnett medium (LBM) and Murashige Skoog Medium favoured the production of depsides such as sphaerophorin and isosphaeric acid. Surprisingly, the mycobiont from H. stevensiae in modified MS medium produced two anthraquinones in the mycelia, haematommone at the base and russulone in the upper parts of the
\end{abstract}

E. Stocker-Wörgötter $(\bowtie) \cdot$ A. Hager

Department of Organismic Biology, University of

Salzburg, Hellbrunner Str. 34, 5020 Salzburg, Austria

e-mail: elfriede.stocker@sbg.ac.at

A. Hager

e-mail: armin.hager@sbg.ac.at

\section{J. A. Elix}

Department of Chemistry, Australian National University, Canberra, ACT 0200, Australia

e-mail: john.elix@anu.edu.au mycelium. By contrast, the natural lichen only produced these anthraquinones in the reddish orange apothecia. The mycobiont from $H$. flourescens only produced the expected lichexanthone in LBM, enriched with the polyols, sorbitol and mannitol. Once the media requirements and environmental stress factors that trigger polyketide production in lichen mycobionts have been determined, it is possible to obtain a particular lichen product by a completely defined procedure. Using such knowledge, we should be able to study polyketide expression in mycobionts under optimized culture conditions for various genetic applications.

Keywords Lichens - Secondary chemistry · Polyketides - Mycobiont cultures · Haematommone · Russulone

\section{Introduction}

Species of the genus Haematomma have their major distribution in tropical, subtropical and oceanic habitats where they colonise the bark of trees and rock outcrops (cortical and saxicolous species). Forty-one species of Haematomma sensu strictu have been described (Staiger and Kalb 1995; Nelsen et al. 2006; Aptroot 2007; Brodo et al. 2008) and accepted but further new species might be expected when 
further sorediate species are included (Brodo et al. 2008) and additional taxa from unexplored tropical or subtropical regions are examined.

The morphology of the typical white and greyish crustose thalli of Haematomma species are rather uniform, but the thickness of the thallus and its surface characteristics are more variable. Such variations may be adaptations to a particular environment rather than to phenotypic species variability (Rogers 1982).

Most species of Haematomma can readily be recognized by their intense red or reddish orange, lecanorine apothecia, but some sorediate species are typically sterile and may need further taxonomic investigation using molecular methods (Brodo et al. 2008).

Haematomma species can best be determined by using a combination of morphological and chemical characters (Staiger and Kalb 1995; Brodo et al. 2008) and are ideal candidates for chemotaxonomic studies.

Species of Haematomma produce five types of aromatic polyketides (depsides, depsidones, dibenzofurans, xanthones, anthraquinones), as well as aliphatic compounds and terpenes (Culberson 1964, 1969; Elix 1994, 2004; Staiger and Kalb 1995).

One objective of our investigation was to find appropriate culture conditions for Haematomma mycobionts that would trigger the production of typical aromatic polyketides (depsides, dibenzofurans) in the aposymbiotically grown mycelium. In a second series of experiments we aimed to study the production of typical polyketide pigments (e.g. the anthraquinones russulone and haematommone) that are produced by the fruiting bodies of species of the genus Haematomma.

\section{Materials and methods}

Selected species of Haematomma were collected in North America (Alabama), Mexico (Baja California Sur), South America (Brazil) and Australia (Queensland).

Haematomma fenzlianum Massal.: Mexico, Baja California Sur, La Huerta, $24^{\circ} 04^{\prime} \mathrm{N}, 110^{\circ} 12^{\prime} \mathrm{W}$.

Haematomma persoonii (Fée) Massal.: United States of America, Alabama, Mobile, Historic Blakely State Park, $30^{\circ} 42^{\prime} \mathrm{N}, 87^{\circ} 57^{\prime} \mathrm{W}$ (field trip of 2003 Botanical Congress, Mobile, Alabama).

Haematomma flourescens Kalb and Staiger: Brazil, Pernambuco, Calvary Mountain, Pesqueira, $8^{\circ} 21^{\prime} \mathrm{S}, 36^{\circ} 43^{\prime} \mathrm{W}$.
Haematomma africanum (J. Steiner) CW Dodge: Australia, Queensland, Fitzroy Island, $16^{\circ} 56^{\prime} \mathrm{S}$, $145^{\circ} 33^{\prime} \mathrm{E}$.

Haematomma stevensiae Rogers: Australia, Queensland, close to the road leading up to Atherton Tablelands near Cairns, $16^{\circ} 42^{\prime} \mathrm{S}, 145^{\circ} 33^{\prime} \mathrm{E}$.

\section{Mycobiont cultures}

Applied nutrient media

The basic medium for culturing the mycobionts of Haematomma species was LBM (Lilly and Barnett Medium) with various additional ingredients, as specified below:

LBM + B [Lilly-Barnett-Medium with bark extract (Lilly-Barnett 1951)] which contains glucose as carbohydrate source, agar, asparagine, thiamine, biotin and various mineral nutrients $(\mathrm{Mg}, \mathrm{K}, \mathrm{Fe}, \mathrm{Zn}, \mathrm{Mn}$ ) in addition to the bark extract prepared by the method of Esser (1976).

LBM $+4 \%$ glucose, $2 \%$ sorbitol and $2 \%$ mannitol (for $H$. persoonii).

$\mathrm{LBM}+4 \%$ ribitol and $2 \%$ sorbitol (for $H$. fenzlianum).

MS 3\% sucrose medium [modified MurashigeSkoog medium (Stocker-Wörgötter 2001, 2002)] which contains sucrose, mannitol, malt, casein, agar and the Murashige mineral salts.

MS $+4 \%$ sucrose, $2 \%$ ribitol and $2 \%$ sorbitol (for H. stevensiae).

MS $+4 \%$ ribitol, $2 \%$ sorbitol and 2\% mannitol (for $H$. persoonii).

MY [Malt-Yeast medium (Yamamoto et al. 1987; Yamamoto 1990)] which contains malt, yeast extract and agar.

$\mathrm{MY}+2 \%$ ribitol and $2 \%$ sorbitol (for $H$. fenzlianum).

PDA [Potato-Dextrose-Agar medium (Sigma P-2182)] which is an extract of potatoes, glucose and agar. PDA $+4 \%$ extra glucose (for $H$. fenzlianuum).

SAB 2\% [Sabouraud-2\%-glucose-agar medium (Fluka 84086)] and SAB 4\% [modified Sabouraud4\%-glucose-agar (Stocker-Wörgötter 2001, 2002)] which contains polypeptone, glucose and agar. $\mathrm{SAB}+4 \%$ ribitol medium (for H.stevensiae). $\mathrm{SAB} 2 \%+2 \%$ mannitol (for $H$. persoonii). 


\section{Isolation of mycobionts}

The modified Yamamoto-method (Yamamoto 1990; Yamamoto et al. 1993) was used for the isolation of the mycobionts from selected species of Haematomma. Small thallus fragments were washed in bidistilled water containing a drop of Tween 80 , then homogenized in sterile water with a mortar and pestle. The suspension was filtered through two sieves (500 and $150 \mu \mathrm{m}$ mesh). Fragments of the washed and homogenized lichen material (c. 150$200 \mu \mathrm{m}$ wide) were transferred with bamboo sticks into tubes containing the nutrient media specified above. The tubes were kept in the dark (covered by aluminium foil) for approximately 3 months until small fungal colonies had formed. The fungal colonies were then homogenized for sub-culturing on the various media described above.

Isolates were kept in a culture chamber at a temperature of $20^{\circ} \mathrm{C}$ (subtropical species) $14: 10 \mathrm{~h}$ day night cycle, and at 27 and $30^{\circ} \mathrm{C}$, for $12: 12 \mathrm{~h}$ day night regimes with a light intensity of 50-100 and 200$400 \mu \mathrm{E} \mathrm{m}^{-2} \mathrm{~s}^{-1}$, respectively. The contamination rate of the fungal isolates was surprisingly low (an average were analysed by HPLC using a Merck-Hitachi system with two pumps, a DAD (photodiode array detector; 190-800 nm wavelength) and a computer system. Two solvent systems were used: (A) $1 \%$ aqueous orthophosphoric acid and methanol in the ratio 7:3 and (B) pure methanol. The run started with $100 \% \mathrm{~A}$ and was raised to $58 \% \mathrm{~B}$ within $15 \mathrm{~min}$, then to $100 \% \mathrm{~B}$ after a further $15 \mathrm{~min}$, followed by isocratic elution in $100 \% \mathrm{~B}$ for a further $10 \mathrm{~min}$. The spectra were identified by means of a spectrum library (comparison with reference substances), and chemical data (Huneck and Yoshimura 1996). TLC was performed using the standardized method with 3 solvent systems (Culberson and Ammann 1979; Culberson and Kristinsson 1969).

\section{Results}

The voucher specimens of Haematomma from the diverse tropical habitats showed considerable variation in the production of cortical, epithecial (apothecia) and medullary secondary metabolites, as can be seen in Schedule 1 below.

\begin{tabular}{lcccccccc}
\hline Haematomma sp. & Atr & Chlatr & Isosph & Sph & Plac & Lichex & Haematom & Russul \\
\hline H. africanum & & & & & $\mathrm{X}$ & & $\mathrm{X}$ & \\
H. fenzlianum & $\mathrm{X}$ & $\mathrm{X}$ & $\mathrm{X}$ & $\mathrm{X}$ & & & & $\mathrm{X}$ \\
H. flourescens & $\mathrm{X}$ & & & $\mathrm{X}$ & & $\mathrm{X}$ & $\mathrm{X}$ & $\mathrm{X}$ \\
H. persoonii & $\mathrm{X}$ & $\mathrm{X}$ & $\mathrm{X}$ & $\mathrm{X}$ & & & & $\mathrm{X}$ \\
H. stevensiae & $\mathrm{X}$ & & $\mathrm{X}$ & $\mathrm{X}$ & & & & $\mathrm{X}$ \\
\hline
\end{tabular}

Atr atranorin, chlatr chloroatranorin, isosph isosphaeric acid, sph sphaerophorin, plac placodiolic acid, lichex lichexanthone, haematom haematommone, russul russulone

of $20-30 \%$ ), depending on the origin of the lichen samples and the sugar contents of the media.

\section{Chemical analyses}

For the chemical analyses, sterile mycobiont cultures (c. $1.0-1.5 \mathrm{~cm}$ diameter) were cut out of the agar plates and freeze-dried at $-42^{\circ} \mathrm{C}$ for at least $12 \mathrm{~h}$. Dried cultures and small pieces of the original lichen thalli were extracted in methanol for $4 \mathrm{~h}$; then the extracts were transferred to HPLC vials. The secondary metabolites of the thalli and mycobiont cultures
The majority of the mycobionts were isolated from small thalline fragments because the numerous spores (present in the apothecia) demonstrated a very low germination rate and furthermore, the few isolated spore-derived cultures showed very slow growth ratea, e.g. $\sim 1 \mathrm{~mm}$ (in diameter) mycelial growth was observed after an incubation time of 3 months.

However, the hyphal isolates from thalline fragments achieved growth rates comparable to those of fruticose and foliose lichen mycobionts. This suprising result indicates that the nutrients available to natural Haematomma species are very limited and probably account for their slow growth rates. 
The production of cortical and epithecial pigments in the selected Haematomma mycobionts was shown to be strongly dependent upon the composition of the nutrient media, in particular the nature of the carbon sources supplied. In many cases reduced growth rates combined with environmental stress (exposure to increased light intensities and temperature drops of $5^{\circ} \mathrm{C}$, e.g. after $4-6$ months, indicated that the mycobionts invested most energy in biochemical processes instead of in further growth and began producing secondary metabolites.

Interestingly, the mycobionts not only produced typical polyketides present in the cortex or the medulla of the natural lichens, but also the polyketide pigments haematommone and russulone present in the fruiting bodies of the natural lichen. Our experiments clearly showed that the Haematomma-mycobionts (supplied with carbon sources and in particular, sugar alcohols) were capable to produce anthraquinone pigments in the absence of symbiotic algae. In the case of $H$. flourescens, lichexanthone was found in juvenile mycelia that were exposed to long wave UV light of $365 \mathrm{~nm}$ for several hours (3-4 h), every week over a time span of 3-4 months (Fig. 3d), while in the natural lichen, this substance is present in the thallus and thalline exciple.

The selected cultured mycobionts showed alternative chemical profiles dependent upon the composition of the medium as can be seen illustrated in Schedule 2 below.
The $H$. africanum mycobiont was the only one that was successfully grown from spore isolates. After an incubation period of 5 months the fungus produced the dibenzofuran, placodiolic acid, and haematommone normally present in the fruiting bodies of the intact lichen.

The $H$. fenzlianum mycobiont was successfully grown from lichen fragments. Three different nutrient media (see Schedule 2 below) were tested. The best results were obtained with $\mathrm{LBM}+4 \%$ ribitol and $2 \%$ sorbitol; in this case the mycobiont formed the typical medullary depsides isosphaeric acid and sphaerophorin after an incubation period of 6 months. In MY $+2 \%$ ribitol and $2 \%$ sorbitol only the sphaerophorin was formed while in Potato-Dextrose medium with additional glucose no lichen metabolites were detected, but droplets of fatty acid were common on the mycelia.

Haematomma flourescens is a species which produces cortical lichexanthone in addition to atranorin. Lichexanthone, as indicated by the yellow fluorescence of the thallus and thalline exciple of the apothecia under UV light (Fig. 1c). Lichexanthone can also be detected by microcystallisation, where the typical straw-yellow crystals of this metabolite can be observed among colourless crystals of sphaerophorin (Fig. 1a-c). Haematomma flourescens was collected in a secondary forest on the twigs of trees

\begin{tabular}{|c|c|c|c|}
\hline Mycobionts & Media & Polyketides produced & Environmental stress factors \\
\hline H. africanum & $\mathrm{MS}+3 \%$ sucrose & Haematommone, placodiolic acid & $\begin{array}{l}\text { Exposure to longwave } \\
\text { UV }(365 \mathrm{~nm})\end{array}$ \\
\hline H. fenzlianum & $\begin{array}{l}\text { LBM }+4 \% \text { ribitol, } 2 \% \text { sorbitol } \\
\text { MY }+2 \% \text { ribitol, } 2 \% \text { sorbitol } \\
\text { PDA-Medium }+4 \% \text { extra glucose }\end{array}$ & $\begin{array}{l}\text { Isosphaeric acid, sphaerophorin } \\
\text { No lichen metabolites }\end{array}$ & $\begin{array}{l}\text { Desiccation } \\
\text { Standard culture conditions }\end{array}$ \\
\hline H. flourescens & $\begin{array}{l}\text { LBM }+4 \% \text { glucose } \\
2 \% \text { sorbitol, } 2 \% \text { mannitol }\end{array}$ & $\begin{array}{l}\text { Lichexanthone in the uppermost } \\
\text { hyphae of the mycelium }\end{array}$ & $\begin{array}{l}\text { Exposure to longwave UV } \\
(365 \mathrm{~nm})\end{array}$ \\
\hline \multirow[t]{3}{*}{ H. persoonii } & $\mathrm{LBM}+4 \%$ ribitol $4 \%$ sorbitol & Isosphaeric acid chloroatranorin & $\begin{array}{l}\text { Desiccation and exposure } \\
\text { to lower temperatures }\end{array}$ \\
\hline & $\begin{array}{l}\text { MS }+4 \% \text { ribitol, } 2 \% \text { sorbitol, } \\
2 \% \text { mannitol }\end{array}$ & $\begin{array}{l}\text { Isosphaeric acid, sphaerophorin, } \\
\text { traces of russulone }\end{array}$ & $\begin{array}{l}\text { Desiccation and exposure } \\
\text { to long wave UV }\end{array}$ \\
\hline & SAB $2 \%$ glucose, $2 \%$ mannitol & No lichen metabolites & Standard culture conditions \\
\hline \multirow[t]{2}{*}{ H. stevensiae } & SAB $4 \%$ ribitol & Haematommone & $\begin{array}{l}\text { Desiccation and exposure } \\
\text { to long wave UV }\end{array}$ \\
\hline & $\begin{array}{l}\text { MS }+4 \% \text { sucrose } \\
2 \% \text { ribitol } 2 \% \text { mannitol }\end{array}$ & $\begin{array}{l}\text { Russulone in upper mycelium, } \\
\text { haematommone at base of } \\
\text { mycelium }\end{array}$ & $\begin{array}{l}\text { Exposure to lower temperatures } \\
\text { and long wave UV }\end{array}$ \\
\hline
\end{tabular}


Fig. 1 a-d Haematomma flourescens. a Haematomma flourescens (Pernambuco, Brazil), voucher specimen. b Lichexanthone crystal, obtained by a microcrystallisation test (GAW). c H. flourescensthallus and apothecia, under long wave (365 nm) UV-light, showing straw yellow UV fluorescence of lichexanthone (notice lichexanthone also in the rims of the fruiting bodies!). d Mycobiont, grown on LBM $4 \%$ glucose, $2 \%$ sorbitol, $2 \%$ mannitol medium, producing lichexanthone in the uppermost hyphae of the mycelium
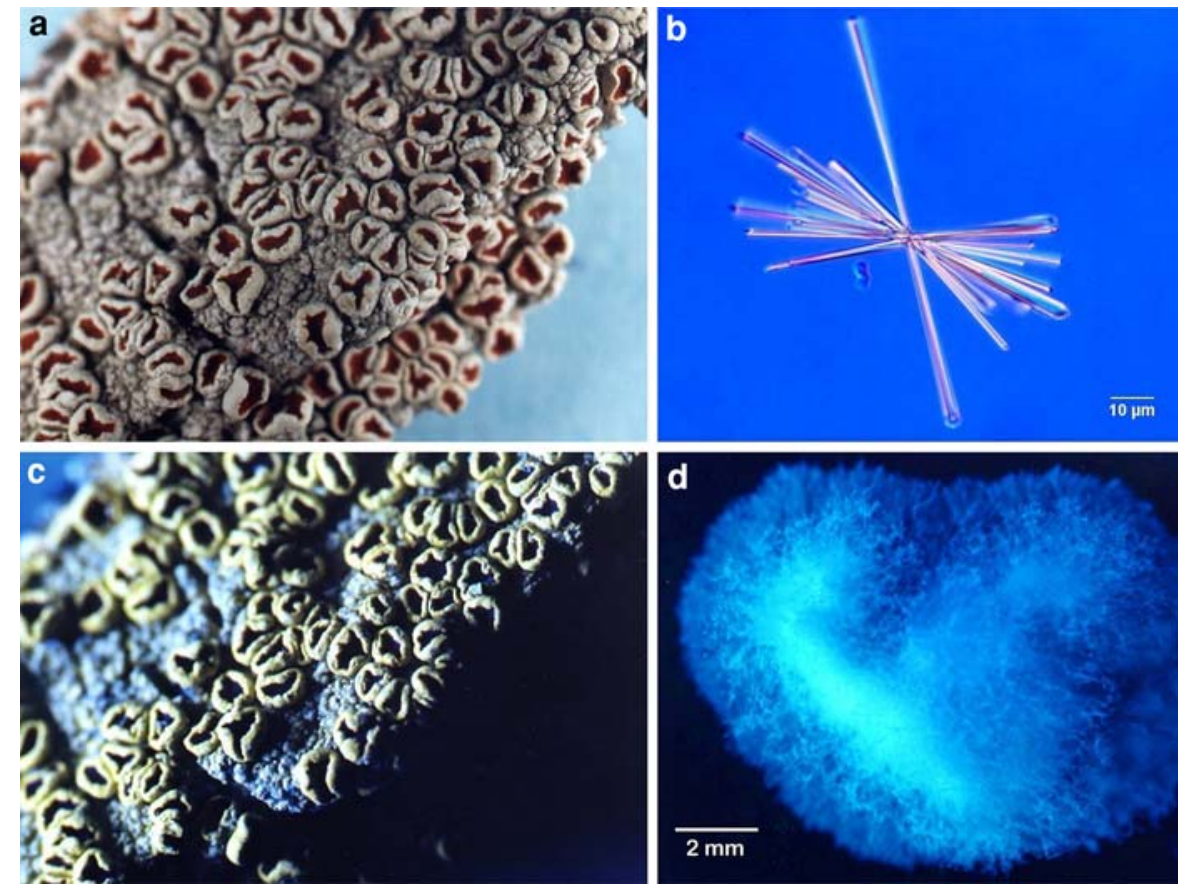

growing in a dry savannah often with sparse foliage; as a result some trees have green stems which also participate in photosynthesis.

Lichens growing on such branches are exposed to intense sunlight and the lichexanthone may act as a complementary light filter to protect the algal populations from the high intensity of solar radiation present in such tropical habitats.

When we exposed the $H$. flourescens mycobiont cultures to repeated long wave UV irradiation for
Fig. 2 a-d Haematomma persoonii. a Haematomma persoonii (Baja California), voucher specimen.

b Mycobiont on SAB 2\% glucose $2 \%$ mannitol medium, producing no lichen substances, 4-monthold subculture.

c Mycobiont, grown on LBM 4\% ribitol 4\% sorbitol agar, producing isosphaeric acid and chloroatranorin. d Mycelium, cultured on MS 4\% ribitol 2\% sorbitol $2 \%$ mannitol medium, producing isosphaeric acid, sphaerophorin and traces of russulone
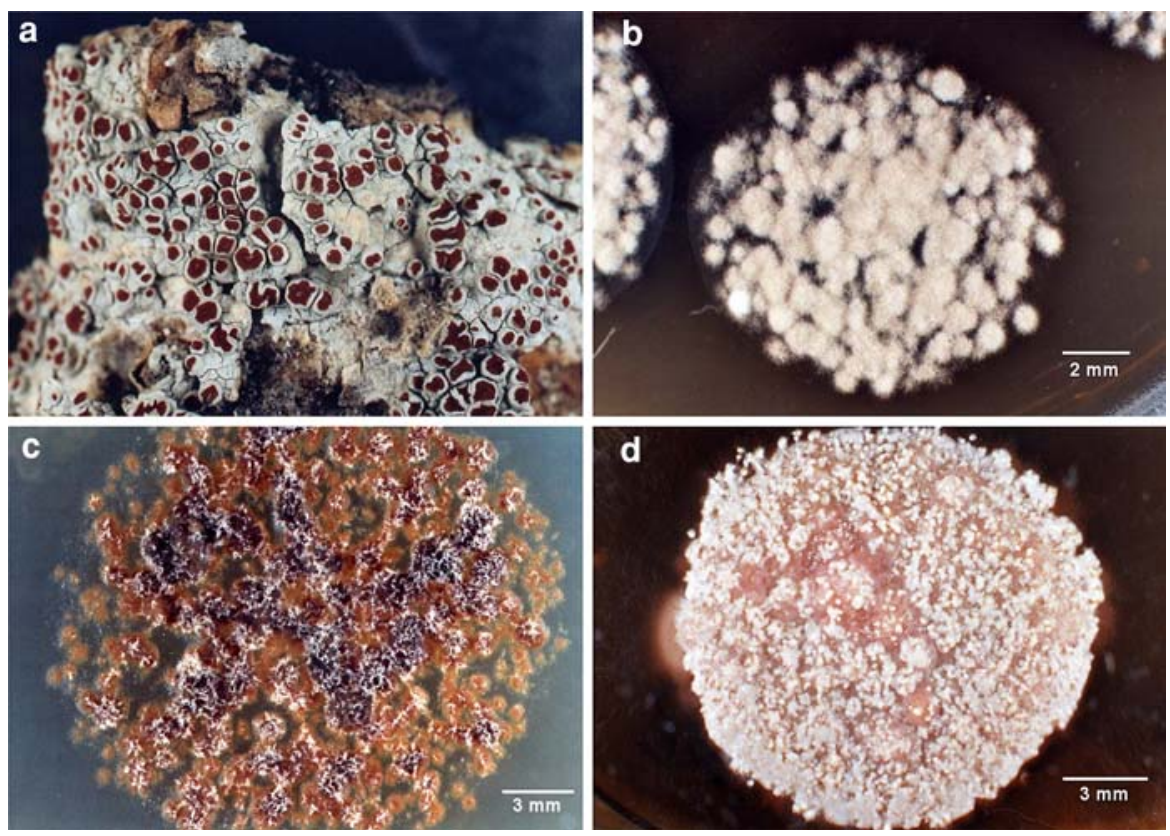
several hours, lichexanthone was formed by the uppermost hyphae of the mycelia as illustrated in Fig. 1d (UV flourescence).

Haematomma persoonii (Fig. 2a) is a pantropical crustose lichen known from Africa, Asia, North and South America, Australia and the Pacific Islands. The mycobiont of $H$. persoonii was also isolated from thallus fragments and demonstrated the highest growth rates among the species studied.

Using SAB 2\% glucose, 2\% mannitol and agar under standard culture conditions (without environmental stress), the cultured mycobionts (Fig. 2b) did not form any lichen substances, as indicated by HPLC analyses.

However, using a MS $+4 \%$ ribitol, $2 \%$ sorbitol and $2 \%$ mannitol medium, the mycelia repeatedly formed isosphaeric acid, sphaerophorin and traces of russulone (Fig. 2d). Interestingly, on LBM medium containing low concentrations of ribitol and sorbitol, the mycobionts produced only isosphaeric acid and chloroatranorin (Fig. 2c).
Fig. 4 a-h HPL-chromatograms and UV spectra. a Chromatogram of Haematomma flourescens (containing lichexanthone). b Chromatogram of Haematomma persoonii, containing the depsides atranorin, isosphaeric acid and sphaerophorin. c UV spectrum of isosphaeric acid (depside). d UV spectrum of sphaerophorin (depside). e UV spectrum of lichexanthone (xanthone). f UV spectrum of placodiolic acid (dibenzofuran in $H$. africanum). g UV spectrum of haematommone (anthraquinone, epithecial pigment, fruiting bodies). h UV spectrum of russulone (anthraquinone, epithecial pigment, fruiting bodies)

The mycobionts of $H$. stevensiae thrived both on $\mathrm{SAB}+4 \%$ ribitol as well as on $\mathrm{MS}+4 \%$ sucrose, $2 \%$ ribitol and $2 \%$ mannitol medium. On the first medium the mycobiont produced only haematommone, whereas on the second more complex medium, the fungus produced hamatommone on the upper part of the mycelium and russulone at the base, forming a ring of highly concentrated reddish orange substance around the mycobiont. This result is of considerable interest, as the voucher specimens of $H$. stevensiae are only known to produce russulone (Fig. 3a, b). In
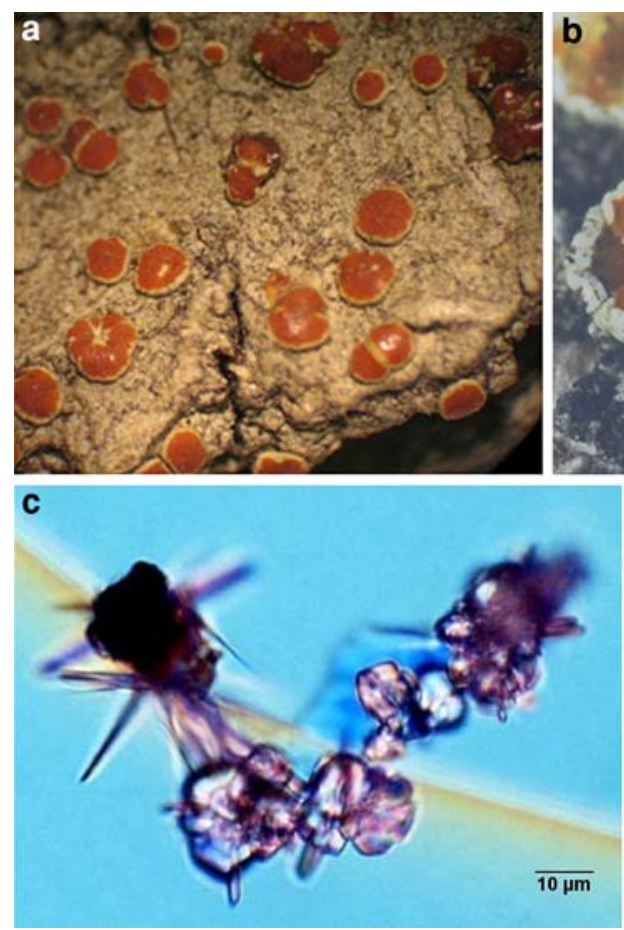

Fig. 3 a-d Haematomma stevensiae. a Haematomma stevensiae, specimen in the herbarium. (Canberra, Australia). b Haematomma stevensiae, voucher specimen from Queensland, Australia containing only the anthraquinone russulone. $(8 \times$, magnified). c Crystals of haematommone and granules of
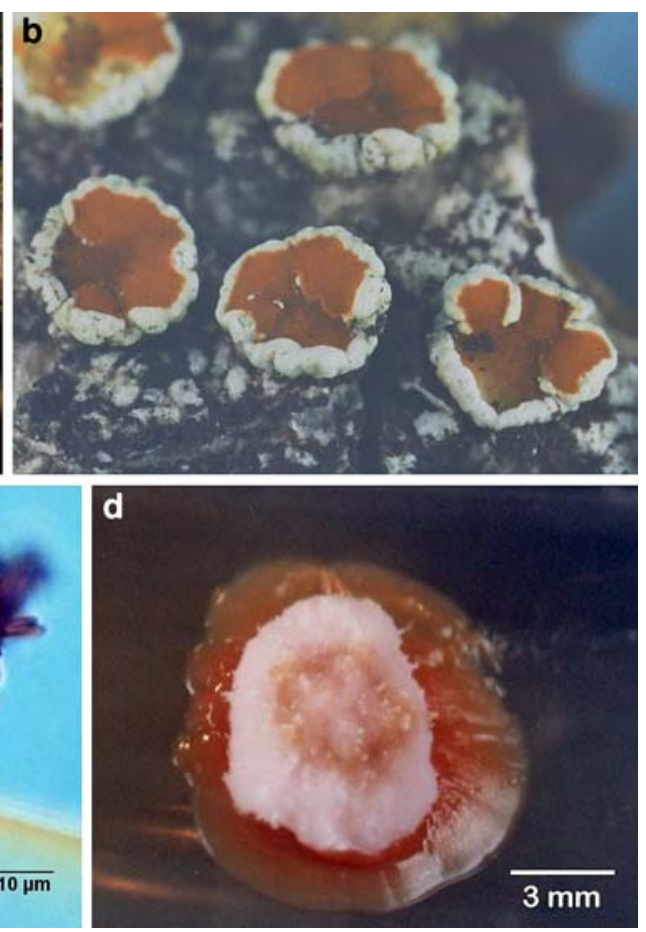

russulone (re-crystallized). d Cultured mycobiont on MS $+4 \%$ sucrose, $2 \%$ ribitol, $2 \%$ mannitol agar (1.5\% Difco), producing russulone on the top and pure haematommone on the base 
Phytochem Rev (2009) 8:561-569

567
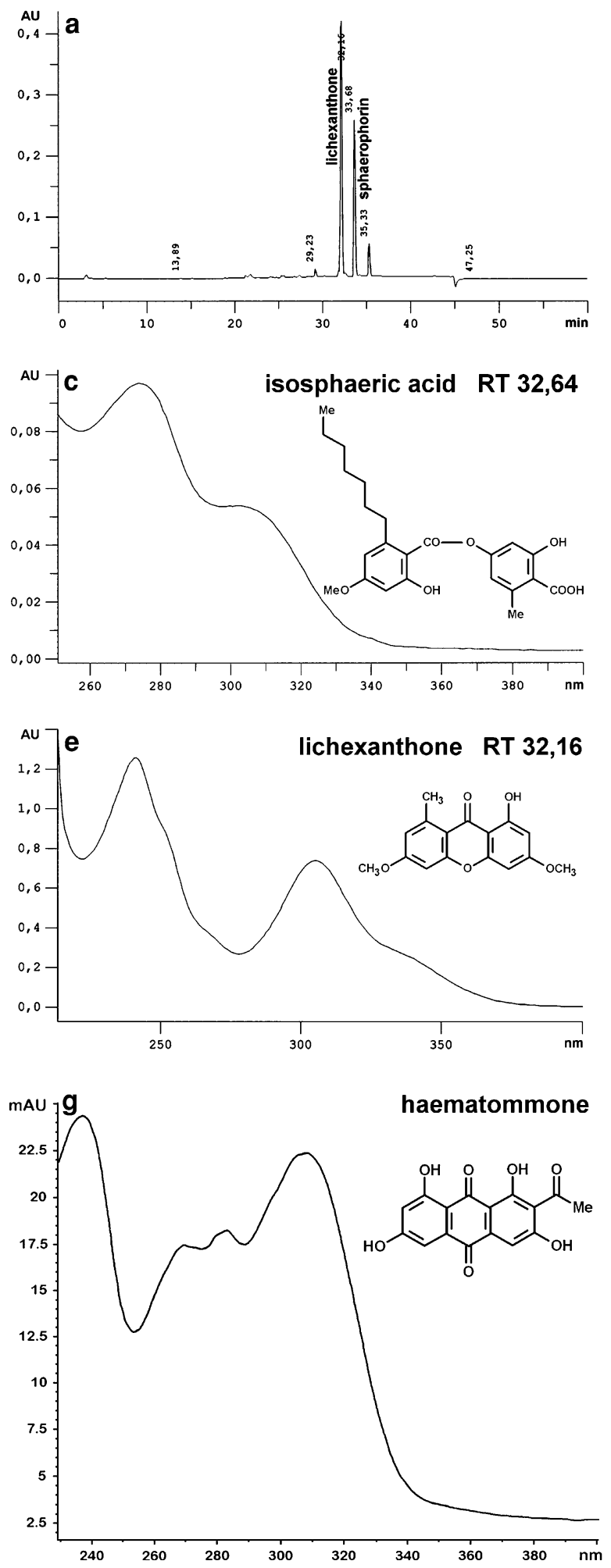
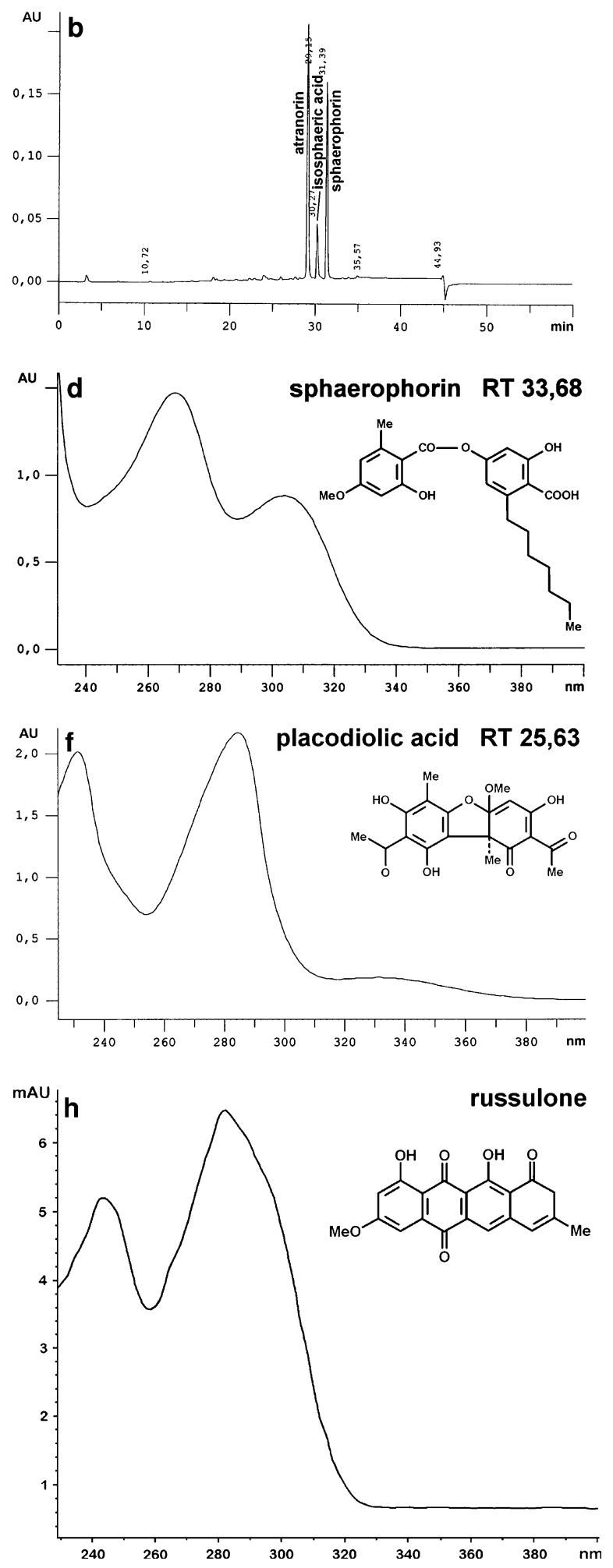

Springer 
contrast, under the artificial laboratory conditions using the particular medium, the production of both anthraquinone pigments could be induced in the fungus (Fig. 3c, d).

The anthraquinone pigments could be isolated by exhaustive extraction with acetone (they are very sparingly soluble in methanol and difficult to detect by HPLC analysis) and recrystallized to form crystals of russulone and granules of haematommone (Fig. 3c).

The chemical profile of $H$. flourescens is documented in Fig. $4 \mathrm{a}$, and that of $H$. persoonii, in Fig. 4b.

The characteristic UV spectra of the polyketides detected in the species of Haematomma are illustrated in Fig. 4c-h.

\section{Conclusions}

The chemical profile of the cultured Haematomma mycobionts was shown to be dependent upon the culture conditions, nutrient supply and environmental factors.

Our experiments established that mycobiont cultures of Haematomma species are excellent model systems to study variations in secondary metabolism in more detail; highlighted by the finding that the mycobiont of $H$. stevensiae has the biochemical capacity to produce both haematommone and russulone, whereas the intact lichen is reported to produce only russulone. The nature of the anthraquinone pigment is considered an important taxonomic character and has been used to separate $H$. stevensiae from other taxa.

Such findings clearly indicate that molecular studies on the genus Haematomma are required in order to understand the relationships between species and the significance of observed variations in chemical profiles in different populations of a particular taxon. Our study showed that under favourable culture conditions, Haemmtomma mycobionts may produce significant quantities of selected polyketides which may well be useful for further investigations.

As found in previous studies (e.g. Molina et al. 2003), our experiments also established that increased mycobiont growth rates do not favour polyketide production, but when growth is impeded by induction of epigenetic (cell differentiation) and biochemical processes, the lichen fungi may switch from fatty acid to polyketide biosynthesis. The FAS and PKS pathways are closely related and there is some indication that they are controlled by the same genes or gene clusters. Kauffmann and Hertweck (2002) demonstrated that even particular fatty acids are biosynthesized by polyketide synthases.

In a study by Adler et al. (2004), the fatty acids and triacylglycerides produced by cultured mycobionts under standardized conditions have actually been identified.

In our previous study with mycobiont cultures of Bunodophoron patagonicum, a lichen producing two rare dibenzofurans (Stocker-Wörgötter and Elix 2004) — we found that dibenzofuran production was only observed in spore-derived cultures. Similarly, we only detected placodiolic acid (a dibenzofuran present in a number of Haematomma species) in the mycobiont of $H$. africanum when it was cultivated from the germinated spores.

In a parallel experiment with mycobiont cultures of $H$. africanum (unpubl. results), no identifiable lichen metabolites were detected although droplets of fatty acids were quite common. The question why particular dibenzofurans are only produced in spore derived mycobiont cultures is still obscure and not resolved.

Acknowledgments ESt-W. is very grateful to the Austrian Science Foundation (FWF) for financial support (P_18210 and P_20887). Tina Hametner is thanked for help with the references. ESt-W is very grateful to Dr. Chris Cargill (Curator at the lichen Herbarium, Australian National Botanical Gardens) for her generous support to do studies of Australian Lichens at ANBG during several stays in Canberra, Australia.

\section{References}

Adler M, Fazio A, Bertoni MD, Rosso ML, Maier MS, Thell A (2004) Culture experiments and DNA verification of a mycobiont isolated from Punctelia praesignis. Bibl Lichenol 88:1-8

Aptroot A (2007) New lichens from Thailand, mainly microlichens from Chiang Mai. Fungal Divers 24:75-134

Brodo IM, Culberson WL, Culberson CF (2008) Haematomma (Lecanoraceae) in North and Central America, including the West Indies. Bryologist 111:363-423. doi:10.1639/ 0007-2745(2008)111[363:HLINAC]2.0.CO;2

Culberson WL (1964) A summary of the lichen genus Haematomma in North America. Bryologist 66:224-236

Culberson CF (1969) Chemical and botanical guide to lichen products. The University of North Carolina Press, North Carolina, Chapel-Hill 
Culberson CF, Ammann K (1979) Standardmethode zur Dünnschichtchromatographie von Flechtensubstanzen. Herzogia 5:1-14

Culberson CF, Kristinsson HD (1969) A standardized method for the identification of lichen products. J Chromatogr A 46:85-93. doi:10.1016/S0021-9673(00)83967-9

Elix JA (1994) Additonal lichen records from Australia. 18. Haematomma saxicola R.W. Rogers from Lord Howe Island. Australas Lichenol Newsl 35:13-14

Elix JA (2004) Haematommataceae. In: Flora of Australia, vol 56A, Lichens 4. Australian Biological Resources Study, Canberra, pp 4-10

Esser K (1976) Kryptogamen: blaugalgen, algen, pilze, flechten. Springer, Berlin, Heidelberg, New York

Huneck S, Yoshimura I (1996) Identification of lichen substances. Springer, Berlin, Heidelberg

Kauffmann U, Hertweck C (2002) Biosynthese ungesättigter Fettsäuren durch Polyketid-synthasen. Angew Chem 114(11):1947-1950. doi:10.1002/1521-3757(20020603) 114:11<1947:AID-ANGE1947>3.0.CO;2-1

Lilly VG, Barnett HL (1951) Physiology of the fungi. McGraw-Hill, New York, pp 10-23

Molina MC, Crespo A, Vicente C, Elix JA (2003) Differences in the composition of phenolics and fatty acids of cultured mycobiont and thallus of Physconia distorta. Plant Physiol Biochem 41:175-180. doi:10.1016/S0981-9428 (02)00017-7

Nelsen MP, Lücking R, Chaves JL, Sipman HJM, Umaňa L, Navarro E (2006) A first assessment of the Ticolichen biodiversity inventory in Costa Rica: the genus
Haematomma (Lecanorales: Lecanoraceae). Lichenologist 38:251-262. doi:10.1017/S0024282906005573

Rogers RW (1982) The corticolous species of Haematomma in Australia. Lichenologist 14:115-129. doi:10.1017/S002 4282982000267

Staiger B, Kalb K (1995) Haematomma Studien. I. Die Flechtengattung Haematomma. II. Lichenicole Pilze auf Arten der Flechtengattung Haematomma. Bibliotheca Lichenologica 39:227

Stocker-Wörgötter E (2001) Experimental studies of the lichen symbiosis: DNA-analyses, differentiation and secondary chemistry of selected mycobionts, artificial resynthesis of two- and tripartite symbioses. Symbiosis 30:207-227

Stocker-Wörgötter E (2002) Resynthesis of photosymbiodemes. In: Kranner I, Beckett R, Varma A (eds) Protocols in lichenology: culturing, biochemistry,ecophysiology and use in biomonitoring. Springer, New York, pp 47-60

Stocker-Wörgötter E, Elix JA (2002) Secondary chemistry of cultured mycobionts: formation of a complete chemosyndrome by the lichen fungus of Lobaria spathulata. Lichenologist 34:351-359. doi:10.1006/lich.2002.0395

Yamamoto Y (1990) Studies of cell aggregates and the production of natural pigments in plant cell culture. Nippon Paint Public, Osaka

Yamamoto Y, Mizuguchi R, Takayama S, Yamada Y (1987) Effects of culture conditions on the growth of Usneaceae lichen tissue cultures. Plant Cell Physiol 28:1421-1426

Yamamoto Y, Miura Y, Higuchi M, Kinoshita Y, Yoshimura I (1993) Using lichen tissue cultures in modern biology. Bryologist 96:384-393. doi:10.2307/3243868 